\title{
Full-scale modelling of an ozone reactor for drinking water treatment
}

\author{
Wim T.M. Audenaert ${ }^{1,2}$, Manly Callewaert ${ }^{1}$, Ingmar Nopens ${ }^{2}$, Jan Cromphout $^{3}$, Robert Vanhoucke ${ }^{3}$, Ann \\ Dumoulin $^{1}$, Pascal Dejans ${ }^{1}$, and Stijn W.H. Van Hulle ${ }^{1,2}$ \\ Corresponding author: Wim.Audenaert@Howest.be
}

${ }^{1}$ EnBiChem Research Group, Department of Industrial Engineering and Technology, University College West
Flanders, Graaf Karel de Goedelaan 5, 8500 Kortrijk

${ }^{2}$ BIOMATH, Department of Applied Mathematics, Biometrics and Process Control, Ghent University, Coupure Links 653, 9000 Gent

${ }^{3}$ VMW, Flemish Water Supply Company, Beliardstraat 73, 1040 Brussels, Belgium

\begin{abstract}
In 2003, the Flemish Water Supply Company (VMW) extended its drinking water production site in Kluizen (near Ghent, Belgium) with a combined ozonation and biological granular activated carbon filtration (BGAC) process. Due to this upgrade, biostability increased, less chlorination was needed and drinking water quality improved significantly. The aim of this study was to describe the full-scale reactor with a limited set of equations. In order to describe the ozonation process, a model including key processes such as ozone decomposition, organic carbon removal, disinfection and bromate formation was developed. Kinetics were implemented in WEST $^{\circledR}$ and simulation results were compared to real data. The predicting performance was verified with a goodness of fit test and key parameters were determined through a local sensitivity analysis. Parameters involving optical density (both rate constants and stoichiometric coefficients) strongly affect model output Some parameters with respect to bromate and bacteria showed to be only, but to a large extent, sensitive to their associated concentrations. A scenario analysis was performed to study the system's behavior at different operational conditions. It was demonstrated that the model is able to describe the operation of the full-scale ozone reactor, however, further data collection for model validation is necessary.
\end{abstract}

Keywords: advanced oxidation processes, ozone, kinetic model, organic contaminant, full scale drinking water production

\section{Introduction}

In order to produce high quality drinking water from surface water resources, a combination of physical and chemical treatment steps is typically used. To achieve good bacteriological quality, chlorine is often used as oxidising agent. However, it is well established that chlorine can lead to many problems in the aquatic environment due to the formation of potential toxic organochlorine compounds such as tetrachloroethene, trichloroethene and halo-acetic acids [1]. Besides this, emerging pollutants and endocrine disruptors (EDC's) became important contaminants in water systems during the last few decades. In order to minimize this byproduct formation and to remove harmful compounds, advanced oxidation processes (AOP's) have already proven to be effective technologies [2,3]. Besides the potential benefits in drinking water production, AOP's have a large potential for the treatment of different types of water and waste streams originating from waste water, such as domestic and industrial effluent, sludge and membrane concentrates, swimming pool water and process water. Both low and high concentrated flows can be treated with AOP techniques [4,5]. Most techniques are based on the formation of hydroxyl radicals which are the strongest oxidators that can be 
used in water treatment systems. Hydroxyl radicals can be generated in water through different combinations of oxidants, like ozone and hydrogen peroxide, or by combining a single oxidant with UV radiation [6]. AOP techniques such as ozonation are either used for (1) the complete or partial oxidation of the organic contamination, (2) the oxidation of a specific contaminant or (3) the removal of pathogens. However, it should be noted, that ozone also produces disinfection by-products (DBP) such as bromate which is formed out of bromide and considered to be a potential human carcinogen [7]. Ozone is used for removal of MIB (2-methylisoborneol) in drinking water production installations as this component is responsible for odour and taste problems [8]. The stage 1 and stage 2 rules, promulgated by US EPA (Environmental Protection Agency), defined a MCL (maximum contaminant level) of $10 \mu \mathrm{g} \mathrm{l}^{-1}$ bromate for systems using ozone [9]. In Europe a similar regulatory level is applied since 1998 (98/83/EC). If the incoming water contains high bromide levels, bromate formation can be restricted by e.g. adding hydrogen peroxide $\left(\mathrm{H}_{2} \mathrm{O}_{2}\right)$ to the ozonation process, [2]. In this case, hydroxyl radicals become important players.

Despite the many advantages and added value of the AOP techniques, there still exist several bottlenecks and research questions concerning these techniques. First, scale-up of lab-scale research reactors to full-scale industrial reactors is often failing. Second, further research on process control and optimisation is necessary. Third, the removal of organic components and micro-organisms is not yet completely unravelled. Modelling of AOP processes offers an elegant and cost-effective tool to tackle these research questions.

Many different attempts have already been made to describe ozone decomposition with or without the presence of organic compounds [10,11]. Two general accepted deterministic models for ozone decomposition in "pure water" have been developed in the early 80's, both based on the first model of Weiss [12]. The model of Staehelin, Hoigné and Bühler, known as the SHB model, was experimentally developed at acidic to neutral $\mathrm{pH}$ 's $[13,14]$ while Tomiyasu, Fukutomi and Gordon (TFG) developed their model at high $\mathrm{pH}$ values [15]. A comparision of both, together with some simulation results can be found in [16]. On the other hand, numerous empirical and semi-empirical studies describing ozone decomposition $[17,18]$, reactions with organic compounds [16,18], by-product formation [19] and disinfection [20] were conducted the last decades. Lovato and co-workers extended the SHB model with an empirical approach by relating one of the 18 kinetic constants to the solution $\mathrm{pH}$ [17]. Van der Helm described ozone decomposition and organic compound removal by using UV absorbance at $254 \mathrm{~nm}\left(\mathrm{UVA}_{254}\right)$ as surrogate for the NOM concentration [18]. Sohn et al. developed an empirical relation to predict bromate formation related to several operational and water quality parameters [19].

In this contribution a simplified model is presented for the simulation of the full-scale ozone reactor of the Flemish Water Supply Company (VMW) in Kluizen (Belgium). The aim of this study is to describe this process with a limited set of equations, to determine the key parameters and to perform different scenario analysis. The results will be used as a starting point for further model development, especially in terms of extending the mechanisms of organic compound removal and biodegradability enhancement. As such, the model might contribute to answering the research questions stated above.

The $60,000 \mathrm{~m}^{3}$ day $^{-1}$ water treatment plant (WTP) which is subject of this study is fed with raw water captured from lowlands. Until 2003, the treatment concept consisted of microsieving, enhanced coagulation followed by sludge blanket clarification, oxidation with chlorine, sand filtration and granular activated carbon filtration (GAC). A final disinfection with chlorine was applied [21,22]. The intensive chlorination resulted in high trihalomethanes (THM) levels and prevented biofilm growth on the activated carbon granules. Due to the absence of biological activity and limited contact time in the GAC (15 minutes), NOM removal was mainly by adsorption, which is limited to the first 10,000 bed volumes (BV, a 
unit that expresses the volume of water that already passed through the filter as a multiple of the volume of the filter bed). In 2000 the earthy-musty taste and odour compound MIB appeared in the feed water with concentrations above the odour threshold value of $10 \mathrm{ng} \mathrm{l}^{-1}$, caused by algal growth in the reservoirs. This, along with a lack of biostability of the water due to high TOC levels, forced the drinking water company to search for an effective oxidizing technique. An ozone production and mixing unit was introduced, together with biological granular activated carbon (BGAC) filters. Ozone was implemented for both disinfection and oxidation. Due to the excellent disinfection capacities, a first chlorination step could be omitted. On the other hand, ozone was also implemented to enhance biodegradability in favour of the biofilm present in the BGAC to remove MIB and NOM. Only a final chlorination step remained [21,22].

\section{Material and methods}

\subsection{Ozone reactor}

Ozone is produced from oxygen with two Wedeco EFFIZON ${ }^{\circledR}$ ozone generation units, each with a production capacity of $4000 \mathrm{~g} \mathrm{~h}^{-1}$ (180 $\mathrm{g}$ ozone per $\mathrm{Nm}^{3}$ oxygen/ozone mixture). The ozone generating elements consist of discrete borosilicate glass tubes with a diameter less than $11 \mathrm{~mm}$. A part of the main water stream is pumped up and pressured up with a high pressure booster pump. The water is brought into a venture injector where ozonated gas is introduced into the water. The side stream is then re-introduced to the main water-pipe prior to a static mixer. The normally applied ozone dose in the water is $2.5 \mathrm{mg} \mathrm{l}^{-1}$. A schematic overview of the gas transfer process is given in Figure 1. A sampling point is located after the static mixer (before the activated carbon filters). After the mixing is completed, the water proceeds to the BGAC filters. Gas flow as well as ozone concentrations in the gas are continuously monitored in order to evaluate the ozone transfer efficiency. An off-gas ozone destruction system converts any residual or non-dissolved ozone to oxygen so that the ozone concentration in the treated off-gas is lower than $0.1 \mathrm{ppm}[21,22]$.

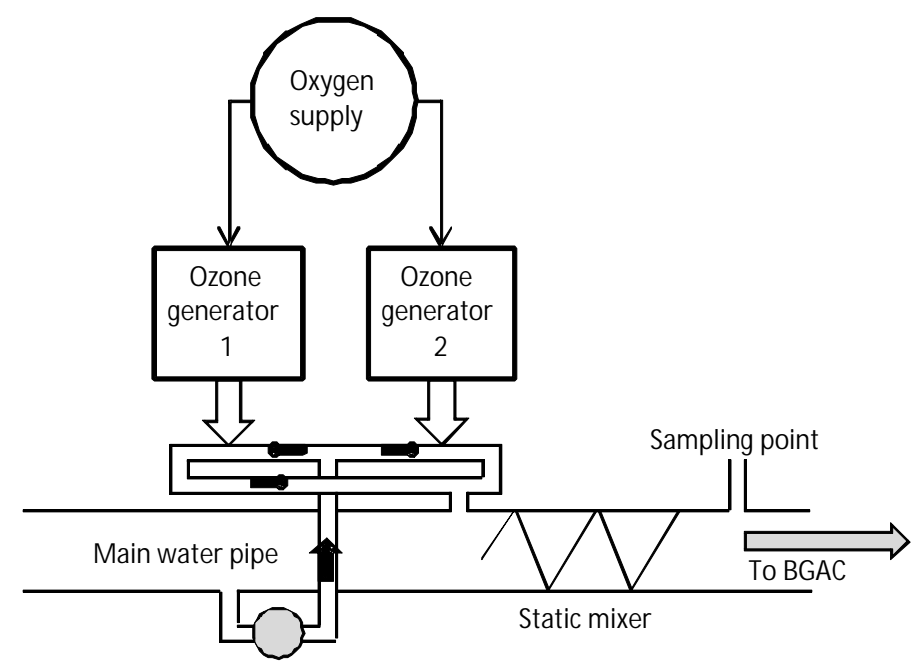

Figure 1: Schematic overview of the ozone production and mixing unit

\subsection{Biological granular activated carbon filters (BGAC)}

The BGAC consists of ten pressure filters with a diameter of 6 meter and operational pressure of 1,5 to 2 bar. GAC is operated as a two-stage filtration, the first filter stage operates between 25,000 and 50,000 BV. After 50,000BV (two years) the carbon is reactivated and the filter is 
switched to the second stage position, which operates between 0 and 25,000BV. A contact time of 6 minutes is obtained in the filters, above the carbon bed. Non-dissolved gas is collected in an upward tee above each GAC filter and led away to the ozone destruction system $[21,22]$.

\subsection{Modelling approach}

The ozone reactor of the Flemish Water Supply Company was implemented in the modelling and simulation platform WEST $^{\circledR}$ (MostforWater, Belgium) as 2 continuous stirred tank reactors (CSTR's) in series. In the first tank with a volume of $10.68 \mathrm{~m}^{3}$ the ozone is introduced. This tank represents the part of the main water pipe before and with the static mixer. A second reactor represents the water on top of the activated carbon filters where a second reaction phase takes place. The simulation configuration as used in the software program is given in Figure 2.

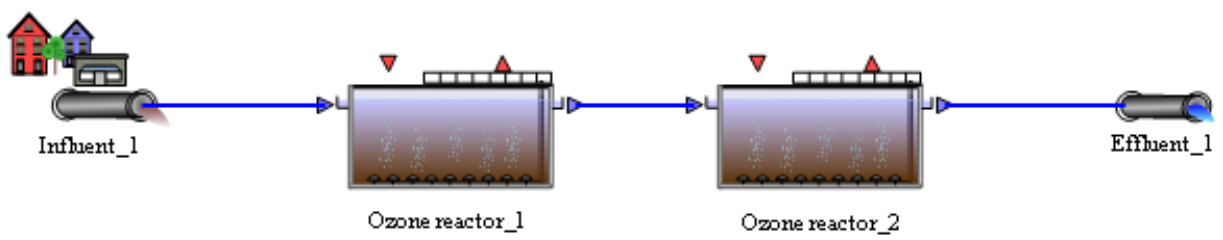

Figure 2: Implementation of the ozone reactor in the simulation platform WEST ${ }^{\circledR}$

Four ozone reactions were implemented in WEST according to [7,11,20,23]

- Ozone decomposition

- Reaction of optical density (OD) with ozone (organic carbon oxidation)

- Disinfection

- Bromide oxidation (bromate formation)

Ozone reactions in water can be classified as either direct or indirect [10,23]. E.g., the disinfection reaction rate can be described by the following equation, where molecular ozone as well as hydroxyl radicals contribute to the oxidizing capacity of the system:

$\rho=\left(k_{O_{3}}+k_{O H} R_{c}\right)\left[O_{3}\right]\left[\mathrm{X}_{\text {bact }}\right]$ with $\quad R_{c}=\frac{\left[\mathrm{HO}^{\bullet}\right]}{\left[\mathrm{O}_{3}\right]} \approx 10^{-8} \sim 10^{-6}$

With:

$\rho$ : reaction rate, in this example the inactivation rate of bacteria (CFU m $\left.\mathrm{m}^{-3} \mathrm{~s}^{-1}\right)$

$k_{\mathrm{O}_{3}}$ : second order rate constant for the direct reaction of molecular ozone with a specific compound, in this example micro-organisms $\left(\mathrm{m}^{3} \mathrm{~g}^{-1} \mathrm{~s}^{-1}\right)$

$k_{O H}$ : second order rate constant for the indirect ozone reaction pathway of hydroxyl radicals with micro-organisms $\left(\mathrm{m}^{3} \mathrm{~g}^{-1} \mathrm{~s}^{-1}\right)$

$R_{c}$ : the ratio of the concentrations of hydroxyl radicals and ozone

$\left[\mathrm{O}_{3}\right]$ : the concentration of ozone in solution $\left(\mathrm{g} \mathrm{m}^{-3}\right)$

$\left[\mathrm{X}_{\text {bact }}\right]$ : the density of viable micro-organisms, in this model expressed as colonyforming units per liter ( $\mathrm{CFU} \mathrm{\textrm {m } ^ { - 3 }}$ ) 
When $R_{c}$ is assumed to be constant and very little, both direct and indirect reactions can be lumped into one:

$\rho=k_{O_{3}}\left[\mathrm{O}_{3}\right]\left[\mathrm{X}_{\text {bact }}\right]$

However, if the indirect mechanism plays an important role in the oxidation of some calculated species, predictive capabilities of the model will deteriorate because process efficiency in that case highly depends on other process conditions such as scavenger concentrations that are not included in the model. Probably radical reactions indeed occur in the waterworks because MIB was removed after ozonation, while rate constants with regard to the direct and indirect pathway are $<10 \mathrm{M}^{-1} \mathrm{~s}^{-1}$ and $3 \times 10^{9} \mathrm{M}^{-1} \mathrm{~s}^{-1}$, respectively [23].

Direct ozone decomposition is modeled assuming that ozone follows a first order decay with a rate constant of $0.000485 \mathrm{~s}^{-1}$ [11]. UV absorbance (optical density) at $254 \mathrm{~nm}$ was used as a surrogate for the amount of organic material that reacts with ozone [11,24]. However, it has to be highlighted that this parameter represents a part of the organic pollution concentration as it specifically gives a measure of the amount of aromatic and unsaturated compounds in water [25]. On the other hand, this parameter offers great opportunities for modelling and control as it can be determined on-line and consequently a huge amount of real-time and accurate data are available. Accordingly, OD might be a useful parameter in model-based control of WTP's.

Model calibration was performed with historical data of the year 2008 over a period of 300 days. For $\mathrm{k}_{\mathrm{OD}}$, which is the rate constant for the reaction of $\mathrm{UVA}_{254}$ with ozone, an initial value in the range of $0.1 \mathrm{~m}^{3} \cdot \mathrm{g}^{-1} \cdot \mathrm{s}^{-1}$ was used [11], while after calibration through parameter estimation a value of $0.0135 \mathrm{~m}^{3} \mathrm{~g}^{-1} \mathrm{~s}^{-1}$ was found. The stoichiometry or yield (Y) of the reaction is represented by $\mathrm{Y}_{\mathrm{O} / \mathrm{OD}}$, with a numerical value of 0.22 [11]. This implies that one unit of $\mathrm{OD}\left(\mathrm{m}^{-1}\right)$ consumes 0.22 grams of ozone.

Disinfection kinetics were adapted from the classic Chick-Watson model [20] (and references therein):

$\frac{d\left[X_{b a c t}\right]}{d t}=-k_{X}\left[\mathrm{O}_{3}\right]\left[\mathrm{X}_{\text {bact }}\right]$

For $\mathrm{k}_{\mathrm{X}}$, the inactivation rate constant for a particular microorganism $\left(\mathrm{m}^{3} \cdot \mathrm{g}^{-1} \mathrm{~s}^{-1}\right)$, a value of 0.6 $\mathrm{m}^{3} \cdot \mathrm{g}^{-1} \cdot \mathrm{s}^{-1}$ was applied after calibration, while the initial value was $1.72 \mathrm{~m}^{3} \cdot \mathrm{g}^{-1} \mathrm{~s}^{-1}$ [11]. The stoichiometry of the reaction is represented by $\mathrm{Y}_{\mathrm{O} 3 / \mathrm{X}}$, with a numerical value of $1.2910^{-14}$ [20].

Bromide oxidation was incorporated as bromate is an important by-product of ozonation in bromide containing waters. Bromide was assumed to be directly oxidized to bromate, although in reality ozone first oxidizes bromide to form hypobromous acid and hypobromite. The latter is further oxidized to bromite which finally forms bromate [23,26,27]. As such, one rate constant for bromate formation was determined after calibration and the stoichiometric coefficients from this process were derived from a reaction where 1 mole of bromate is formed out of 1 mole of both ozone and bromide. The rate constant was found to be 0.00043 $\mathrm{m}^{3} \mathrm{~g}^{-1} \mathrm{~s}^{-1}$.

The kinetics and stoichiometric coefficients used in the model are presented in Table 1 as a Petersen matrix. This matrix presentation offers a clear overview of the chemical reaction 
mechanisms included in the model. Reaction rates are indicated in the right column. Matrix elements are stoichiometry parameters.

Table 1: Petersen matrix representing the model used in this study

\begin{tabular}{|c|c|c|c|c|c|c|}
\hline Process & $\underset{\left(\mathrm{g} \mathrm{m}^{-3}\right)}{\mathbf{O}_{3}}$ & $\underset{\left(\mathbf{m}^{-1} \mathbf{m}^{-3}\right)}{\text { OD }}$ & $\begin{array}{c}\mathbf{X}_{\text {bact }} \\
\left(\mathbf{C F U} \mathbf{~ m}^{-3}\right)\end{array}$ & $\underset{\left(\mathrm{g} / \mathrm{m}^{3}\right)}{\mathrm{Br}^{-}}$ & $\begin{array}{l}\mathrm{BrO}_{3}^{-} \\
\left(\mathrm{g} \mathrm{m}^{-3}\right)\end{array}$ & Reaction rate \\
\hline Ozone decomposition & $-1^{\mathrm{a}}$ & & & & & $\mathrm{k}_{\mathrm{O} 3}\left[\mathrm{O}_{3}\right]$ \\
\hline $\begin{array}{l}\text { Reaction of optical } \\
\text { density with ozone }\end{array}$ & $-\mathrm{Y}_{\mathrm{O} 3 / \mathrm{OD}}{ }^{\mathrm{b}}$ & -1 & & & & $\mathrm{k}_{\mathrm{OD}}\left[\mathrm{O}_{3}\right][\mathrm{OD}]$ \\
\hline Disinfection & $-Y_{O 3 / X}^{c}$ & & -1 & & & $\mathrm{k}_{\mathrm{X}}\left[\mathrm{O}_{3}\right]\left[\mathrm{X}_{\text {bact }}\right]$ \\
\hline Bromide oxidation & -1 & & & -1.66 & 2.66 & $\mathrm{k}_{\mathrm{Br}}\left[\mathrm{O}_{3}\right]\left[\mathrm{Br}^{-}\right]$ \\
\hline
\end{tabular}

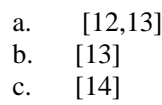

The temperature and $\mathrm{pH}$ influence was not accounted for in this study as these parameters remain almost constant during the waterworks daily operation. Although, for example the inactivation constant for bacteria, $\mathrm{k}_{\mathrm{X}}$, is temperature dependent [20]. With respect to $\mathrm{pH}$, this parameter has a slight effect on the ozone decomposition rate when lower than 7, but at higher values, the rate increases significantly [10]. For instance, von Gunten and Hoigné showed that the half-life of ozone is 10 times higher at $\mathrm{pH} 10$ than that at $\mathrm{pH} 11$ [27]. These researchers also reported that less bromate is formed when lowering the $\mathrm{pH}$. Further, no gas transfer equations were included in the model. A dissolved ozone concentration in the influent of the first tank was defined at the beginning of each simulation run. Finally, the activated carbon present in the second compartment could have a catalytic effect on ozone decomposition. However, this was not considered.

\subsection{Data interpretation}

The goodness-of-fit between experimental and simulated values was quantified by calculating Theil's inequality coefficient (TIC) [28], which is expressed as follows:

$T I C=\frac{\sqrt{\sum_{i}\left(y_{i}-y_{m, i}\right)^{2}}}{\sqrt{\sum_{i} y_{i}^{2}}+\sqrt{\sum_{i} y_{m, i}^{2}}}$

Where:

$\mathrm{y}_{\mathrm{i}}$ represents the simulated data points

$\mathrm{y}_{\mathrm{m}, \mathrm{i}}$ representing the measured data points

A value of the TIC lower than 0.3 indicates a good agreement with measured data [29].

A sensitivity analysis was performed in $\mathrm{WEST}^{\circledR}$ to determine the most important model parameters (those parameters that have a major influence on the model output). The relative sensitivity function (RSF) was adopted to evaluate the sensitivity of the model output 
(concentration of ozone, OD, CFU and bromate) to a change of model parameters (Rate constants $\mathrm{k}_{\mathrm{O} 3}, \mathrm{k}_{\mathrm{OD}}, \mathrm{k}_{\mathrm{X}}$ and $\mathrm{k}_{\mathrm{Br}}$ and the stoichiomtric coefficients $\mathrm{Y}_{\mathrm{O} / \mathrm{OD}}$ and $\mathrm{Y}_{\mathrm{O} 3 / \mathrm{X}}$ )

The RSF was calculated out of the sensitivity function (SF) by the finite forward difference method with a perturbation factor of $0.1 \%$ [30]. This means that SF's were calculated by raising the nominal parameter value with $0.1 \%$ as shown in following equation:

$$
\frac{\partial y}{\partial \theta_{j_{+}}}=\frac{y\left(t, \theta_{j}+\xi \theta_{j}\right)-y\left(t, \theta_{j}\right)}{\xi \theta_{j}}
$$

Where:

$\mathrm{y}\left(\mathrm{t}, \theta_{j}\right)$ represents the output variable

$\theta_{j}$ represents the nominal parameter value

$\xi$ is the perturbation factor

RSF was calculated as following:

$$
R S F=\frac{S F \times \theta}{y(t, \theta)}
$$

A RSF less than 0.25 indicates that the parameter is not influential. Parameters are moderately influential when $0.25<\mathrm{RSF}<1$. When $1<\mathrm{RSF}<2$ and $\mathrm{RSF}>2$, the parameter seems to be very and extremely influential, respectively [31].

\subsection{Analysis}

Ozone was measured spectrophotometrically with the indigo reagent method at $600 \mathrm{~nm}$ [32]. Optical density was constantly measured with a process integrated UV spectrometer at 254 $\mathrm{nm}$. Bromide, bromate and total CFU were analysed according to Standard Methods [33]. All analysis were performed by the Flemish Water Supply Company.

\section{Results and discussion}

\subsection{Modelling results}

Model calibration was performed with historical data of the year 2008 over a period of 300 days. The influent flow rate and optical density are represented in Figure 3 . The influent bacteria and bromide concentration were on average $183 \mathrm{CFU} \mathrm{l}^{-1}$ and $138 \mu \mathrm{g} \mathrm{l}^{-1}$, respectively. The descending trend of the OD can be attributed to improved settling and flotation performance in the pre-treatment steps during that period. 


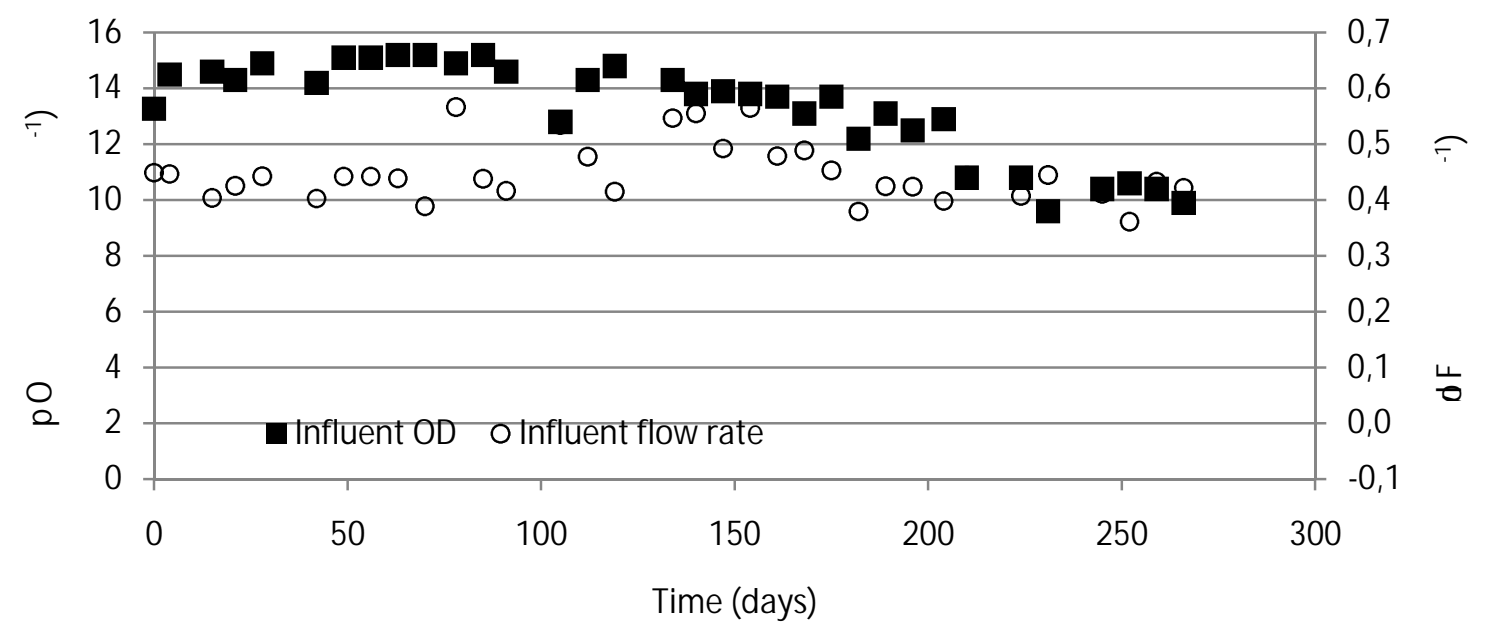

Figure 3: Influent flow rate and optical density

As mentioned before, all samples were withdrawn before the activated carbon bed (after the static mixer). Consequently, all simulation results are representing the effluent of the first reactor in Figure 2. Figure 4 shows the measured and calculated optical density after the first reactor. A good agreement was obtained as the TIC for this parameter is calculated to be $0.044(<0.3)$. The deviation of the applied rate constant for $\mathrm{k}_{\mathrm{OD}}$ in comparision with literature reported values can be explained by differences in organic carbon content of the water.

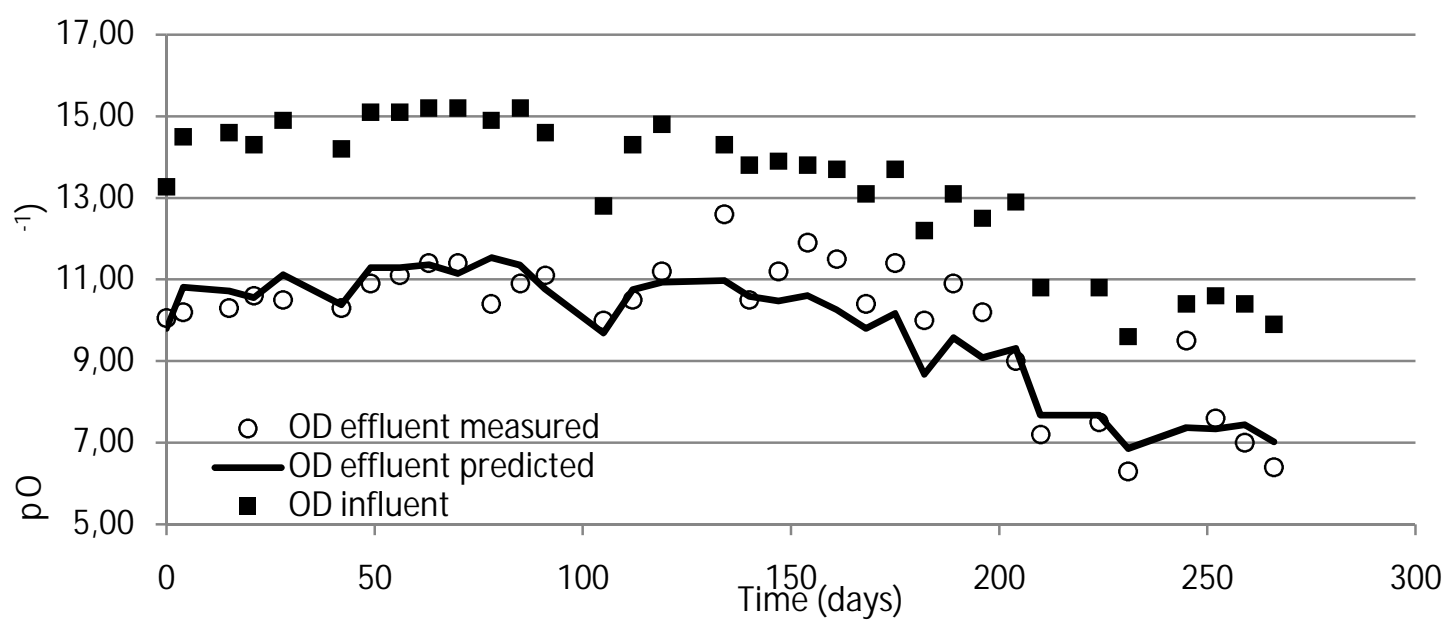

Figure 4: Comparison of measured and calculated optical density

On average, $25 \%$ of the OD was removed for both calculated and modelled values. Concerning the number of CFU, an average log removal of 1.2 was calculated, which is in accordance with the measured removal $(1.1 \mathrm{log})$. Measured influent bacteria concentrations vary between 80 and $200 \mathrm{CFU} \mathrm{1^{-1 }}$ while those of the effluent are in the range of $10 \mathrm{CFU} \mathrm{^{-1 }}$. Calculated and measured bacteria removals are compared in Figure 5. As can be seen, calculated values agree well with experimental ones. This is confirmed with a calculated TIC of 0.084 , although it has to be highlighted that more data points have to be collected in future studies. 


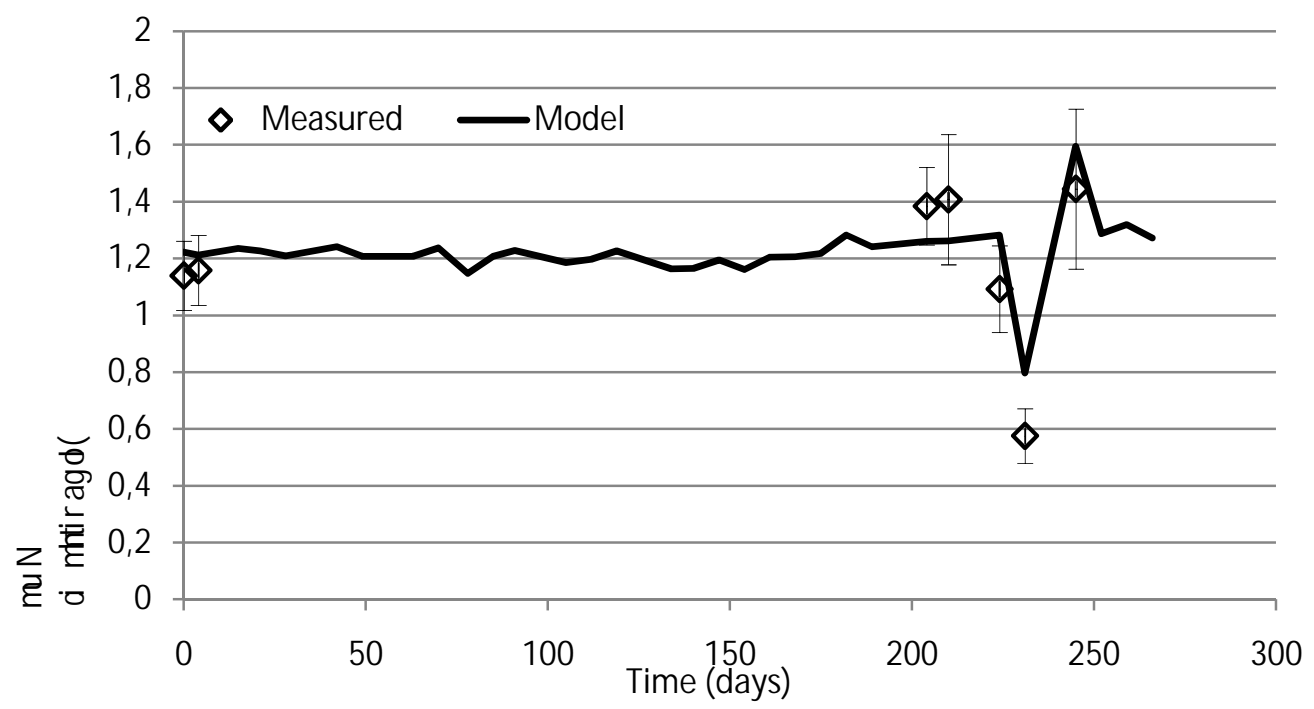

Figure 5: Comparison of measured and calculated logarithmic bacteria removal

Bromate was only measured once $\left(4 \mu \mathrm{g}^{-1}\right)$. Therefore, the average calculated bromate concentration and the measured value are presented in Figure 6. Based on the measured value, it can be seen that model predictions are realistic. In future work, the validation process will be repeated, especially for bromate formation. Measured and calculated values are far below the regulatory level of $10 \mu \mathrm{g} \mathrm{l}^{-1}$.

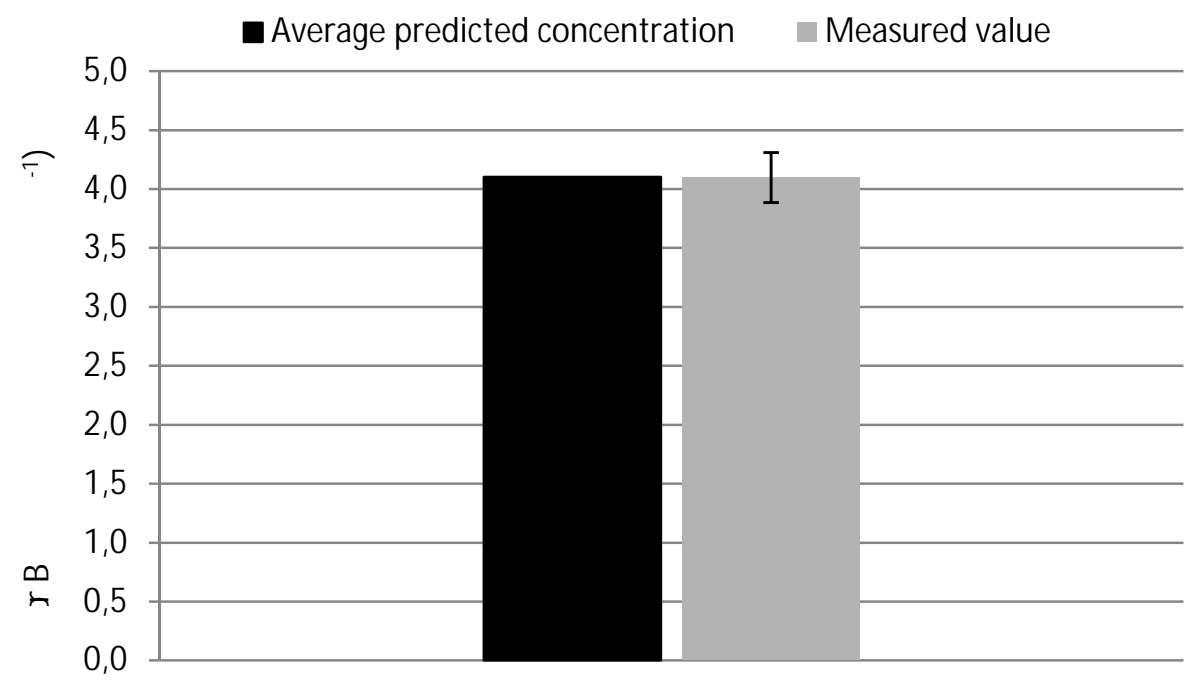

Figure 6: Predicted and measured bromate concentration in the effluent

\subsection{Sensitivity analysis}

The initial parameter values used in the sensitivity analysis are shown in previous paragraphs. It can be clearly noticed that parameters involving $\mathrm{OD}\left(\mathrm{k}_{\mathrm{OD}}\right.$ and $\left.\mathrm{Y}_{\mathrm{O} 3 / \mathrm{OD}}\right)$ strongly affect model output compared to others (Table 2). $\mathrm{k}_{\mathrm{OD}}$ has a moderate effect on calculated ozone, bacteria and bromate concentrations. There's a smaller influence with respect to OD itself. The same conclusions can be made for $\mathrm{Y}_{\mathrm{O} / \mathrm{OD}}$, although moderate effects are slightly higher. $\mathrm{k}_{\mathrm{X}}$ and $\mathrm{k}_{\mathrm{Br}}$ only influence their associated concentrations $[\mathrm{X}]$ and $\left[\mathrm{BrO}_{3}{ }^{-}\right]$. However, due to the very affecting character $(\mathrm{RSF} \approx 1)$, accurate estimation regarding these parameters will be necessary to obtain realistic predictions of bacteria and bromate levels. $\mathrm{k}_{\mathrm{O} 3}$ and $\mathrm{Y}_{\mathrm{O} 3 / \mathrm{X}}$ do not exert an 
influence on simulation output. Bacteria (X) form part of OCS (ozone consuming substances), but they consume a negligible amount of ozone due to their extremely low concentrations [34]. This explains that $\mathrm{Y}_{\mathrm{O} 3 / \mathrm{X}}$ has no effect on the bacteria concentration as the ozone requirement for this reaction is met under normal operational conditions.

Table 2: RSF values indicating the degree influence of model parameters on output variables

\subsection{Scenario analysis}

The effect of applied ozone concentration and flow rate on certain key variables was evaluated. The normally operational ozone dose in the drinking water production centre is 2.5 $\mathrm{mg} \mathrm{l}^{-1}$. Scenario's were calculated for concentrations varying from 0 to $5 \mathrm{mg} \mathrm{l}^{-1}$. Flow rate (and consequently hydraulic retention time) was varied within a range of 0 (batch reactor) to 1 $\mathrm{m}^{3} \mathrm{~s}^{-1}$ while real influent flow rates are in the range of 0.4 to $0.5 \mathrm{~m}^{3} \mathrm{~s}^{-1}$.

Effects of ozone dose on effluent OD and bromate formation are shown in Figure 7. This figure reveals that a compromise has to be made regarding ozone dose and flow rate to comply with bromate levels without losing OD (and bacteria) removal goals. Figure 7 also shows that the normally applied flow rates in this case are in a beneficial range. A significant amount of OD is removed and the bromate level stays well below the standard of $10 \mu \mathrm{g} 1^{-1}$. The influent OD concentration was $11.3 \mathrm{~m}^{-1}$.

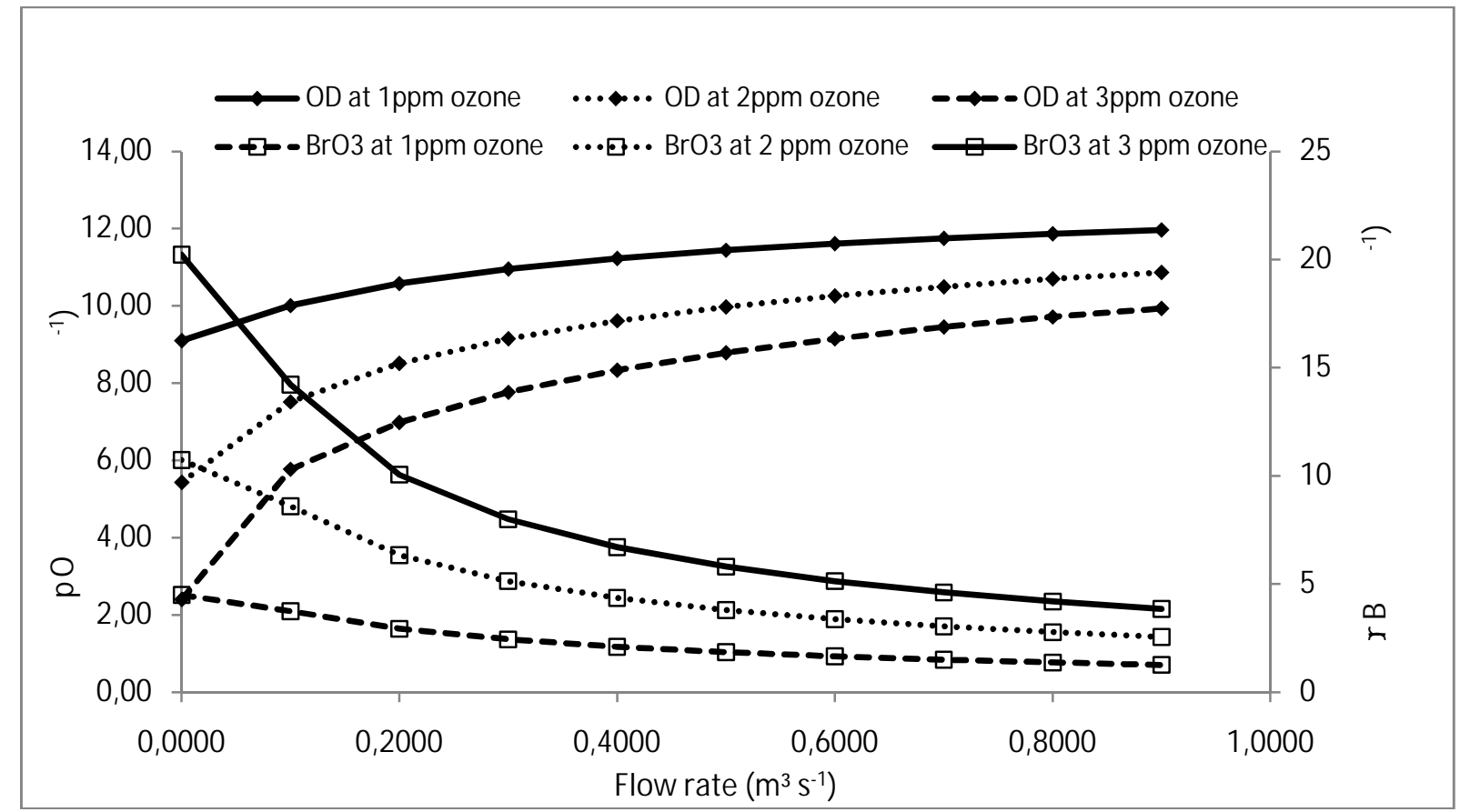

Figure 7: Scenario analysis, effect of flow rate on OD and bromate concentrations 


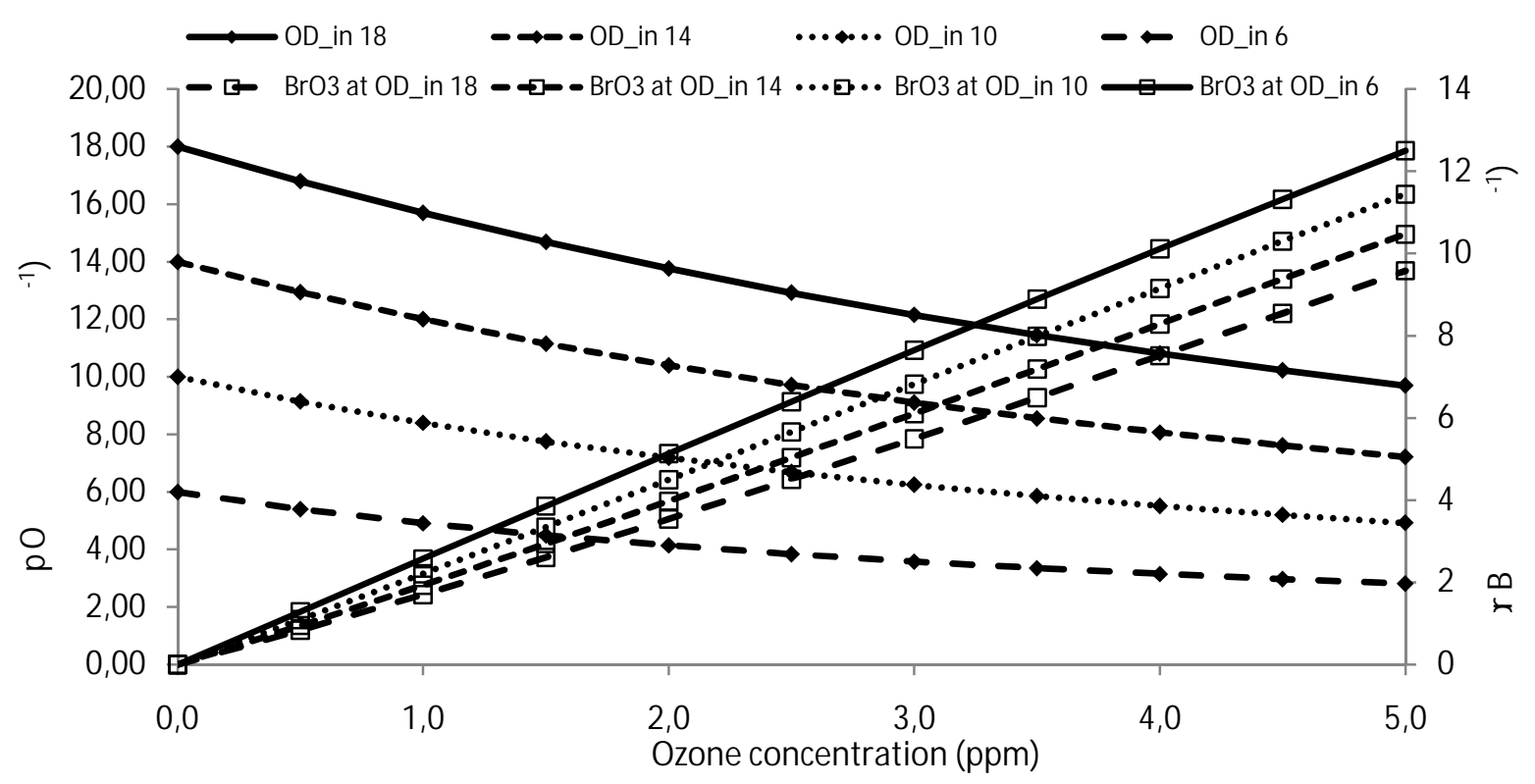

Figure 8: Scenario analysis, effect of ozone dose on OD and bromate concentrations

As can be deduced from Figure 8, the operational ozone concentration of $2.5 \mathrm{mg} \mathrm{l}^{-1}$ is well chosen. Again, sufficient OD is removed and the bromate guideline is met without problems.

\subsection{Bromate formation}

Sohn and co-workers stated that most of the models for predicting residual ozone and bromate formation take empirical functional forms because the complexity of natural organic matter restricts developing complete theoretically based chemical kinetic models [19]. They developed a multiple regression model that was compared to experimental data from the VMW [21] (and references therein):

$$
\left[\mathrm{BrO}_{3}\right]=1.55 \times 10^{-6} \times[\mathrm{TOC}]^{-1.26} \times[\mathrm{pH}]^{5.82} \times\left[\mathrm{O}_{3}\right]^{1.57} \times[\mathrm{Br}]^{0.73} \times t^{0.28} \times(1.035)^{T-20} \text { (Eq. 7) }
$$

Figure 9 shows this comparison. The model developed in this study was added to the graph. The regression model seems to show a better prediction of the experimental data, as also indicated when comparing the TIC values of both, the regression and the kinetic model with values of 0.17 and 0.21 , respectively. However, both models agree well with reality (TIC $<0.3$ ). The over-estimation of bromate by the kinetic model can be caused by inaccurate parameter estimation with insufficient data as $\mathrm{k}_{\mathrm{Br}}$ has proven to be very influential to simulated bromate concentrations (see sensitivity analysis). The assumptions that were made regarding the bromate mechanism, together with not included temperature effects can contribute to less prediction accuracy, together with the fact that only 1 data point was available for calibration. Regression models are able to describe experimental data very well and temperature or reactor correction factors can be easily added [19]. On the other hand, models based on well defined mechanisms can give more substantiated insight in processes and are easier to apply. 


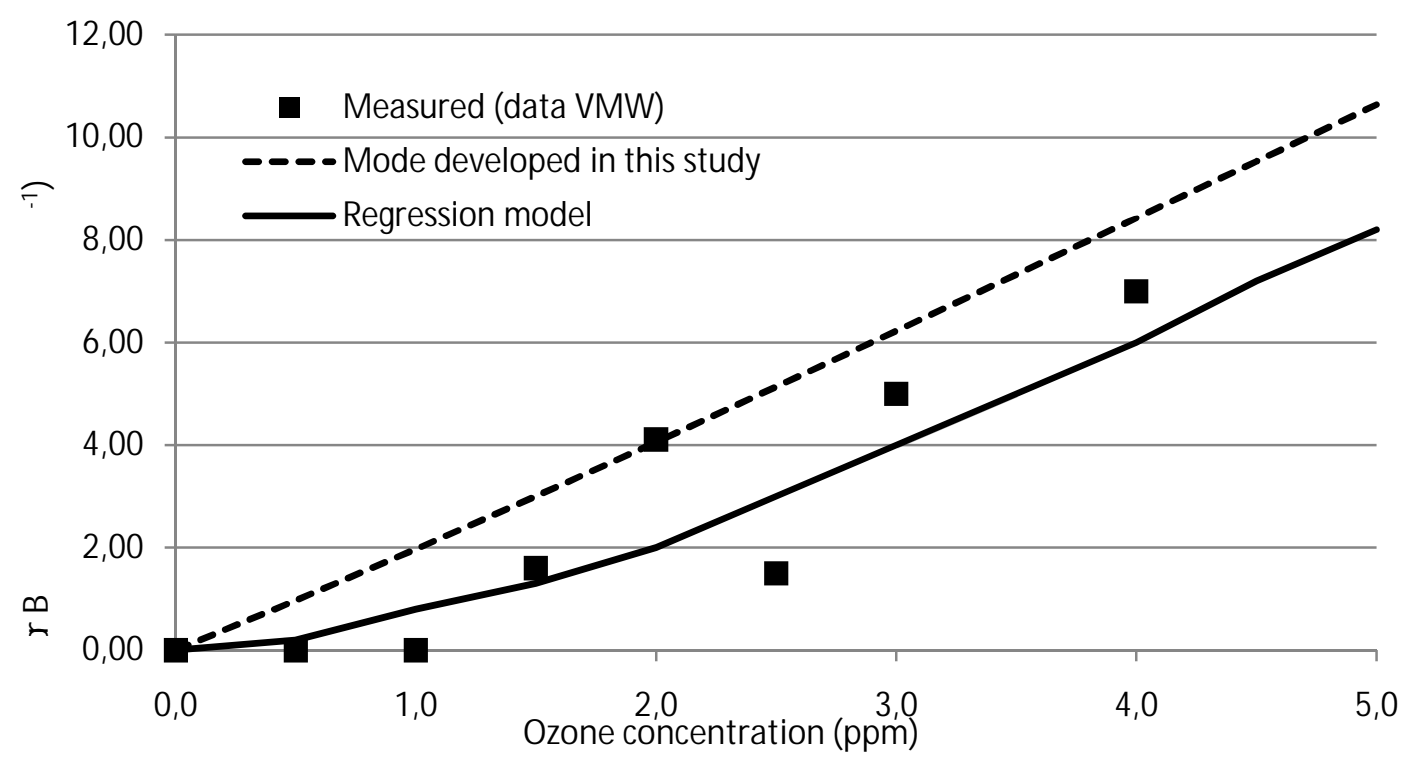

Figure 9: comparison of predicting performance of a regression model and the kinetic model developed in this study.

\section{Conclusions}

In this study, a simplified kinetic model describing ozone decomposition, organic carbon removal, disinfection and bromate formation during ozonation applied in drinking water production was developed. Calibration and simulation runs were based on historical data from a full-scale ozonation system at the Flemish Water Supply Company waterworks in Kluizen, Belgium. It was demonstrated that the developed model is able to predict excess ozone concentration, OD removal, bacteria inactivation and bromate formation, although further data collection and batch experiments will be necessary to further validate the model. A sensitivity analysis revealed that parameters involving optical density (both rate constants and stoichiometric coefficients) strongly affect model output. Some parameters with respect to bromate and bacteria showed to be only, but to a large extent, sensitive to their associated concentrations. OD seems to be a valuable parameter for the application of model-based control and optimization strategies as it can be determined on-line and consequently a huge amount of real-time and accurate data are available.

With drinking water standards becoming more stringent, models will become an important tool to assess drinking water plant performance [35]. This model will be used for further scenario analysis (particularly effect of ozone dosage on reactor performance) and will play an important role in the drinking water modelling studies in Flanders. The model will be used as starting point for a more detailed model which includes radical reactions (i.e. model of Staehelin, Hoigné and Bühler) $[10,13,14]$ and a combination of AOP techniques (ozone, UV, $\mathrm{H}_{2} \mathrm{O}_{2}$ ) to guarantee satisfactory model predictions and to improve the applicability and optimization capacities.

\section{Acknowledgements}

The authors would like to thank the Flemish Water Supply Company (VMW) and in particular Jan Cromphout and Robert Vanhoucke for the fruitful collaboration and making the data of the water purification site available.

This research was partially funded by a University College West Flanders PhD Research Grant. 


\section{References}

[1] J.J. Rook, Formation of haloforms during chlorination of natural water, J Water Treatment Examination 23(2) (1974) 234-243.

[2] M. Werderitsch, Full Scale Advanced Oxidation Treatment Plant for Groundwater. In: M. Sievers, S. Geissen, S. Schäfer, B. Kragert, M. Niedermeiser (Eds.), Proc. 5th IWA International Conference/10th IOA-EA ${ }_{3} \mathrm{G}$ Conference on Oxidation Technologies for Water and Wastewater Treatment, Berlin, Germany, March 30-April 2, 2009, CUTEC publication series, 72 (2009).

[3] C. Boucherie, C. Lecarpentier, N. Fauchon, M. Djaferand and V. Heim, "Ozone" and "GAC Filtration" synergy for emerging micropollutants removal on Drinking Water Treatment Plant?, In: M. Sievers, S. Geissen, S. Schäfer, B. Kragert, M. Niedermeiser (Eds.), Proc. 5th IWA International Conference/10th IOA-EA ${ }_{3} \mathrm{G}$ Conference on Oxidation Technologies for Water and Wastewater Treatment, Berlin, Germany, March 30-April 2, 2009, CUTEC publication series, 72 (2009).

[4] J.C. Crittenden, R.R. Trussell, D.W. Hand, K.J Howe and G. Tchobanoglous, Water Treatment Principles and Design, John Wiley and Sons, Hoboken, USA, 2005.

[5] S.A. Parsons, Advanced Oxidation Process for Water and Wastewater Treatment, IWA Publishing, London, UK, 2005.

[6] W. H. Glaze, J. W. Kang and D. H. Chapin, The chemistry of water treatment processes involving ozone, hydrogen peroxide and ultraviolet radiation, Ozone Sci. Eng. 9 (1987) 335-342.

[7] U. von Gunten, Ozonation of drinking water: Part II. Disinfection and by-product formation in presence of bromide, iodide or chlorine. Water Res. 37 (2003b) 14691487.

[8] M. Sangehashi, K. Shiraishi, H. Fujita, T. Fujji and A. Sakoda, Ozone decomposition of 2methylisorboneol (MIB) in adsorption phase on high silica zeolites with preventing bromate formation, Water Res. 39 (2005) 2926-2934.

[9] National Primary Drinking Water Regulations: Stage 2 Disinfectants and Disinfection Byproducts Rule, Fed. Regist., 71(2) (2006).

[10] J. Beltràn, Ozone Reaction Kinetics for Water and Wastewater Systems, CRC Press LLC, Florida, USA, 2004.

[11] AWC. van der Helm, Integrated modeling of ozonation for optimization of drinking water treatment, $\mathrm{PhD}$ Thesis, Faculty of Civil Engineering and Geosciences, Delft University of Technology (150 pag.), 2007.

[12] J. Weiss, Investigations on the radical $\mathrm{HO}_{2}$ in solution, Trans. Faraday Soc. 31 (1935) 668-681.

[13] R.E. Bühler, J. Staehelin and J. Hoigné, Ozone Decomposition in Water Studied by Pulse Radiolysis. 1. $\mathrm{HO}_{2} / \mathrm{O}_{2}{ }^{-}$and $\mathrm{HO}_{3} / \mathrm{O}_{3}{ }^{-}$as Intermediates. J. Phys. Chem. 88 (1984) 25602564.

[14] J. Staehelin, R.E. Bühler and J. Hoigné, Ozone Decomposition in Water Studied by Pulse Radiolysis. 2. $\mathrm{OH}$ and $\mathrm{HO}_{4}$ as Chain Intermediates. J. Phys. Chem. 88 (1984) 59996004.

[15] H. Tomyasu, H. Fukutomi and G. Gordon, Kinetics and mechanism of ozone decomposition in basic aqueous solution. Inorg. Chem. 24 (1985) 2962-2966.

[16] P. Westerhoff, R. Song, G. Amy and R. Minear, Applications of ozone decomposition models. Ozone Sci. Eng. 19 (1997) 55-74.

[17] M. E. Lovato, C. A. Martín, A. E. Cassano, A reaction kinetic model for ozone decomposition in aqueous media valid for neutral and acidic $\mathrm{pH}$. Chemical Engineering Journal 146 (2009) 486-497. 
[18] A.W.C. van der Helm, P.W.M.H. Smeets, E.T. Baars, L.C. Rietveld and J.C. Van Dijk, Modeling of ozonation for dissolved ozone dosing. Ozone Sci. Eng. 29 (5) 379-389.

[19] J. Sohn, G. Amy, J. Cho, Y. Lee and Y. Yoon, Disinfectant decay and disinfectant byproducts formation model development: chlorination and ozonation by-products. Water Res. 38(10) (2004) 2461-2478.

[20] N.K. Hunt and B.J. Mariñas, Inactivation of Escherichia coli with ozone: chemical and inactivation kinetics, Water Res. 33 (1999) 2633-2641.

[21] J. Cromphout and R. Vanhoucke, Reduction of exploitation costs and improvement of water quality by the implementation of Ozonization at the Waterworks in Kluizen. In: Proc. IOA-EA ${ }_{3}$ G-VIVAQUA International Conference on Ozone and related oxidants in advanced treatment of water for human health and environmental protection Disinfection, elimination of persistant pollutants and control of by-products, Brussels, Belgium, May 15-16, 2008.

[22] J. Cromphout, E. Walraevens and R. Vanhoucke, Improvement of Water Quality in the Drinking Water Plant of Kluizen by the use of Ozone in Combination with GAC, Tribune de L'Eau 58 (1) (2005) 15-18.

[23] U. von Gunten, Ozonation of drinking water: Part I. Oxidation kinetics and product formation, Water Res. 37 (2003a) 1443-1467.

[24] W. Song, V. Ravindran, M. Pirbazari, Process optimization using a kinetic model for the ultraviolet radiation-hydrogen peroxide decomposition of natural and synthetic organic compounds in groundwater, Chem. Eng. Sci. 63 (2008) 3249-3270.

[25] P. Westerhoff, G. Aiken, G. Amy, J. Debroux, Relationships between the structure of natural organic matter and its reactivity towards molecular ozone and hydroxyl radicals. Water Res. 33(10) (1999) 2265-2276.

[26] W. R. Haag and J. Hoigné, Ozonation of bromide-containing waters: kinetics of formation of hypobromous acid and bromate, Environ. Sci. Technol. 17 (1983) 261267.

[27] U. von Gunten and J. Hoigné, Bromate Formation during Ozonation of BromideContaining Waters: Interaction of Ozone and Hydroxyl Radical Reactions, Environ. Sci. Technol. 28 (1994) 1234-1242.

[28] H. Theil, Economic Forecasts and Policy, 2nd ed., North Holland Publishing Co, Amsterdam, 1961.

[29] X. Zhou, A new method with high confidence for validation of computer simulation models for flight systems, Chinese J. Syst. Eng. Electron, 4 (1993) 43-52.

[30] D.J.W. De Pauw and P.A. Vanrolleghem, Practical aspects of sensitivity function approximation for dynamic models, Math. Comp. Modell. of Dyn. Sys. 12 (2006) 395414.

[31] T. Jiang, X. Liu, M.D. Kennedy, J.C. Schippers and P.A. Vanrolleghem, Calibrating a side-stream membrane bioreactor using Activated Sludge Model No. 1, Wat. Sci. Tech. 52 (2005) 359-367.

[32] H. Bader and J. Hoigné, Determination of ozone in water by the indigo method, Water Res. 15 (1981) 449-456.

[33] Standard Methods for the Examination of Water and Wastewater, 18th ed., American Public Health Association Inc., New York, 1992.

[34] T. Huang, C. J. Brouckaert, M. Pryor, C. A. Buckley, Application of computational fluid dynamics modelling to an ozone contactor, Water SA 30 (2004) 51-56.

[35] S.W.H. Van Hulle, J. Verstraete, J. Hogie, P. Dejans, A. Dumoulin, Modelling and simulation of a nitrification biofilter for drinking water purification, Water SA, 32 (2) (2006) 257-264. 